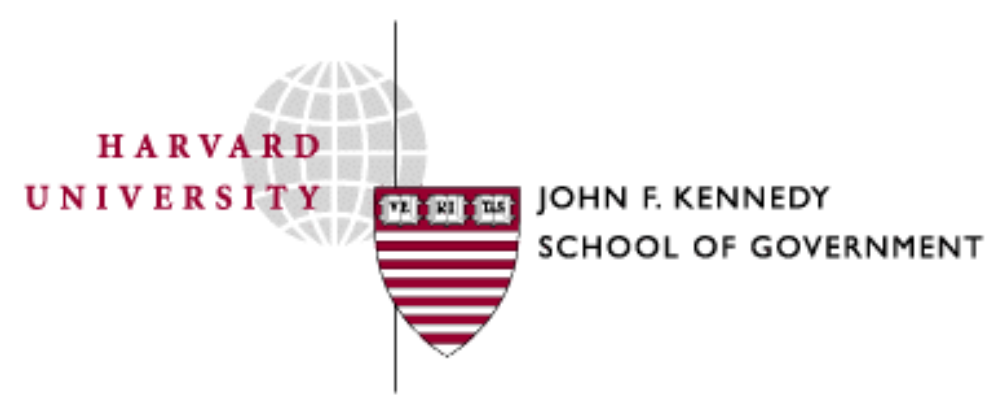

Faculty Research Working Papers Series

The Management Performance of the U.S. States

\author{
David C. King \\ Richard J. Zeckhauser \\ Mark T. Kim
}

July 2004

RWP04-028 belongs to the author(s). Papers may be downloaded for personal use only. 


\title{
The Management Performance of the U.S. States
}

\author{
David C. King \\ Richard J. Zeckhauser \\ Mark T. Kim \\ John F. Kennedy School of Government \\ Harvard University \\ Special to American Politics Research
}

July 8, 2004

This paper was underwritten by a grant from the Center for Innovations in American Government at Harvard University. We thank Alberto Abadie, Lamar Alexander, Alan Altshuler, Derek Bok, Cary Coglianese, Suzanne Cooper, Tara Fisher, Daniel Franklin, Tom Gais, Patricia Ingraham, Ira Jackson, Robert Jensen, Dale Jones, Tom Huddleston, David Lazer, Lant Pritchett, and Robert Putnam for their support and their suggestions

David C. King is Associate Professor of Public Policy, John F. Kennedy School of Government, Harvard University. 79 JFK Street, Cambridge, MA 02138. Richard J. Zeckhauser is Professor of Public Policy at the JFK School, and Mark T. Kim is a recent graduate of the Kennedy School. Please direct correspondence to David King@Harvard.edu. 


\begin{abstract}
The Maxwell School's Government Performance Project rated the management successes of the 50 states in several areas, such as capital management, human resources and information technology in 1998 and 2000. Variability among the states was significant. Viewing the Maxwell School data as something to be explained, we focus on political institutions, social characteristics and the economic environments in the states. We review hypotheses that predict management performance, and we test them empirically. We find that states high in social capital, states with professional legislatures, and states with vibrant entrepreneurial economies are more likely to be better managed. A state's tax burden and the governor's powers seem unrelated to the Maxwell School scores. States with a high density of "good government" groups tend to be poor performers, presumably because citizens join such groups hoping to improve their unsatisfactory state governments.
\end{abstract}




\section{Introduction}

To General George Washington awaiting the ratification of the U.S. Constitution, recalcitrant Rhode Island was "Rogues' Island," a land of scandals and petty politics. The states' varied capacities to govern vexed the Founding Fathers. Indeed, stark differences in the governability of the states helped doom the Articles of Confederation and boosted the call for a strong national government. Two hundred twenty-five years later, Rhode Island remains among the worst managed state governments, according to recent studies by the Maxwell School of Government at Syracuse University. A similar study examining the implementation of new management techniques showed Rhode Island among the nation's least likely states to introduce change (Brudney, Herbert \& Wright 1999). By contrast, Virginia’s government, which George Washington and Thomas Jefferson identified as an effective counterpoint to Rhode Island, continues to be well managed and is more likely to adopt new management techniques.

Why are some states well managed, while others fair so poorly? Trying to measure how well a state's government is managed is maddenly difficult (Forsythe 2001), and there is growing concern among scholars that states may adapt their behaviors to pass sometimes-arbitrary performance measures rather than improve public management per se (Hatry 2002). Nonetheless, we are encouraged by recent progress that has, for the most part, been driven by research radiating from Maxwell School scholars involved in the "Government Performance Project" or GPP (Ingraham \& Kneedler 2000).

Explanations of better or worse public management typically raise concepts that have been difficult to measure. Some states have active voters and interest group communities, and there is a clear relationship between citizen mobilization and the responsiveness of politicians (Erikson, Wright \& McIver 1993; Hill \& Leighley 1996; Gray \& Lowrey 1996). A few states traditionally have been more likely to implement innovative programs, acting as little laboratories for democracy, while other states adopt policies only after they have been tried elsewhere (Walker 1969, Gray 1973, Hays 1996, Mintrom 1997). Successful state-level policy 
innovations should be treasured, rewarded and replicated (Altshuler \& Behn 1997, Light 1998).

On the negative side of the ledger, corruption, which varies widely among the states, brews from a state's history and political culture (Meier \& Holbrook 1992, Elazar 1984). Since political institutions and policy outcomes vary widely, the 50 states make "an excellent testing ground for studying the relationship between political institutions and public policy outcomes" (Besley \& Case 2001: 1).

Good management practices - including handling personnel, overseeing budgets, and planning with an eye on the future - are precursors to being able to implement state programs successfully (Ingraham, Joyce \& Donahue 2003). Without good management practices in the states, it is difficult to expect innovative policies to be well designed or well implemented.

Recently the Pew Charitable Trusts engaged Syracuse University's Maxwell School of Citizenship and Public Affairs to conduct GPP. The first report card was issued in 1999 (based on a 1998 survey), followed by a second report card in 2001. The purpose of the GPP was to evaluate the performance of all 50 states in five areas of management (Ingraham \& Moynihan 2001; Ingraham \& Kneedler 2000). These areas included financial management, human resources management, information technology management, capital management, and managing for results.

The Syracuse scholars worked to link their measures of management capacity to policy performance in the states (Hou, Moynihan \& Ingraham 2001). That is an important step, but it is not our objective in this paper. While we do believe that good management practices are a precursor to good public policy implementation, demonstrating the link is beyond the scope of this paper. Rather, we are interested in what might explain the variance among states in how well they are managed, based on the GPP data.

While the GPP reports have generated widespread interest among public management professionals, there has been little systematic examination of the factors correlated with - and perhaps promoting - the successful management of state government. Knack (2002) and Uslaner 
(2004) explored the GPP data in efforts to assess the relationship between performance and a state's social capital (Putnam 2000). Our task in this paper is to explore the social and institutional correlates of "good government" in the states.

Our results are surprising, both for what we find to be important (e.g., states with professional legislatures perform better), and for what we find to be unimportant (e.g., neither a state's dominant political ideology nor the amount of political competition seems to matter). We begin by describing the Maxwell School data on state government performance. Then we outline our expectations, and we analyze the data. We conclude with a call for stronger support for professional legislatures, for improving the social capital infrastructures of states, for actions that enhance the entrepreneurial business climate of states, and for broader distribution of information trumpeting successful policy innovations in the states.

\section{The Management of State Governments}

A long literature in Public Administration has tracked the management performance of state agencies in specific areas, such as personnel management and information technology. Elling's synopsis (1992) explored policy and management areas across all 50 states. Among others, Herbert, Wright and Brudney (1992) urged the careful surveying of management techniques and hoped that the lessons would be widely shared. Once completed, these surveys proved valuable in promoting an emerging consensus around best practices (Chi et al. 1997; Brudney, Herbert \& Wright 1999). With support and publicity from Governing magazine, the Maxwell School's efforts have received the bulk of the attention.

First in 1998 and again in 2000, teams from the Maxwell School crisscrossed the states collecting data and interviewing public servants. The 1998 analysis was done with the help of editors and reporters from Governing magazine, following nearly 1,000 interviews that were conducted in states to assess 35 criteria for performance. (See Appendix A.) These criteria were summarized as grades in five categories, from "financial management" to "managing for 
results." Results for both years are shown in Table 1. The column marked "Grade Point Average" reports the means across the five categories.

\section{(Table 1 About Here)}

Consider, for example, the way that "financial management" grades were determined. Thirteen indicators were used, including whether the state audits financial statements, whether the state adopts its budgets on time, whether the state's revenue forecasts had been accurate, and whether there are management devices to ensure that budgets reflect policy priorities. Considering these and other elements of financial management, New York received a D+ in 1998 while the Utah government got an A. Unlike Utah and a growing number of states, New York has not adopted performance-based budgeting (Willoughby \& Melkers 2001), and while the grades reveal nothing about how well citizens are represented in either state, we can be assured that the budget processes were better managed in Utah. (Similarly, Utah scored very well in Brudney, Herbert and Wright's (1999) analysis of management innovations.) Like any good grading system, the scores the states receive from the Government Performance Project vary considerably.

Table 1 shows scores in the five management categories, the primary findings. States that did well in one category tended to succeed in other ways, too. For example, governments that did well in "financial management" usually also placed well in "managing for results," and so on, though some categories correlated more highly than others. A correlation matrix of the GPP grades is shown in Appendix B, with an A equal to "12" and an F equal to "1." A principal components factor analysis finds one strong underlying "common factor," with each of the five management scores weighted about equally. Accordingly, and for simplicity of interpreting the results, much of our focus is on the "average" grade assigned each state.

Over the last 20 years, various management approaches have been touted as ways to improve government services. Such touted techniques include performance based budgeting, 
total quality management, and treating citizens like consumers (Elling 1999). ${ }^{1}$ The growing literature on how to incubate innovative programs in governments emphasizes the value of giving managers sufficient autonomy to experiment with solutions, to be free to fail, and to expand efforts where successful. As for the state grades, however, the Maxwell School analysis could not identify any particular management approach that worked better than others. "We looked closely," said Dale Jones of the GPP, "and there are no formulas, no two or thee systems or approaches that light the way for the front runners. The common denominator appears to be strong leadership and well integrated systems to improvement management across all the categories, at times with some risk from changing old ways of doing things" (GPP 2001: 2).

\section{Explanations for State Management Performance}

We expect that systematic causes, beyond leadership strategies and management techniques, relate to successful state government performance. There is a long and useful literature on state governments, notably surrounding how and when states innovate and what the interest group environments are like (Gray, Hanson \& Jacob 1999).

We look here at three broad categories: government institutions, the political and social environment in the state, and a state's business environment. We try to be agnostic in our starting views, and the explanations may as such appear to be a laundry list. However, we do have priors, namely that states with high social capital (Knack 2002), states with careful overview from legislatures, and states with well-managed neighbors will tend to be better run.

Our analysis employs the 1998 Grading the States scores. We have greater confidence in the 1998 data because the Maxwell School has provided extensive background materials on how those grades were generated, and while there were updated grades published in 2001, we have

\footnotetext{
${ }^{1}$ Many of these techniques go under the general heading of "performance management," although the "successes" are especially difficult to measure when an agency's task is to prevent the low-probability, albeit very bad, outcomes. Indeed, in many states that are developing performance management systems, these new systems are oddly decoupled from policy shops specializing in program evaluation techniques (Blalock \& Barnow 2001, Sparrow 2000).
} 
not been able to verify how those grades were derived. Furthermore, most of our dependent variables were measured in years closer to the 1998 survey.

\section{$\underline{\text { Government Institutions }}$}

Just as states range from large to small, urban to rural, and rich to poor, political institutions within states vary widely. Some legislatures are powerful and autonomous, others weak and subject to routine interference from the executive branch. Some governors rule with grand authority, while others are severely limited by state constitutions.

Governor's Powers. A hundred years ago legislatures tended to dominate state politics, particularly in appointing U.S. Senators and directing debates over proposed amendments to the federal Constitution. Most governors served under strict term limits and turnover was high. During the 1920s, for example, the 48 states elected 185 new governors (or about 4 new governors in ten years). To some extent, weak governorships reflected the mistrust of executive powers that predated the Revolutionary War. Governorships became more powerful in the mid1900s, and by the 1980s, turnover had dropped dramatically. Indeed, there were just 55 new governors elected in all 50 states during the decade (Beyle 1992).

Today the governor is usually considered to be the most powerful political player in a state. Nevertheless, the power and influence of the governor varies considerably across the states. Beyle (1999) draws a useful distinction between personal and institutional powers of governors. Our measure of executive power flows from his analysis of a governor's institutional powers.

Three institutional arrangements are critical: a governor's budgetary powers, appointive powers, and whether the governor's cabinet is separately elected. Brudney Hebert \& Wright (1999) found that state agencies with leaders who had been appointed by the governor were more likely to implement "reinventing government" management techniques. We expect that the 
governor's control over the bureaucracy should be related to better-managed agencies, though we recognize that many readers may expect political control over a bureaucracy to lead to patronage and inefficiency.

Budgetary powers of the governors differ considerably. In Maryland and West Virginia, the governors have full responsibility for devising a budget, and the state legislatures may not independently increase spending in any areas. In Texas and South Carolina, the governors and legislatures share responsibility for proposing budgets but the legislature has unlimited power to change the executive's budget. As for appointive powers, some governors (like those in Ohio and Vermont) have broad and virtually unchecked powers to appoint people to state boards positions without legislative approval. Other governors (in Massachusetts and Georgia, for example) have limited appointment powers, and even the selection of cabinet officials may have to be done under the watchful eye of a separate board, commission, or legislative committee.

Finally, the extent to which a governor can claim a statewide electoral mandate is a potentially important power. Five states elect governors much as the nation elects presidents, with a governor and lieutenant governor on the ticket but with no other statewide officers. The remaining states have other officials (such as the attorney general, the secretary of state, the treasurer and public utility authorities) elected at the same time, and these other offices are often held by members of the party opposing the governor and by gubernatorial wannabes. As with appointive powers, a governor's institutional powers are weakened when major cabinet positions are held by people with their own statewide constituencies and whom the governor cannot discipline.

Our measure of a governor's institutional powers is derived from a factor score underlying indicators for the three characteristics just discussed. ${ }^{2}$ Budget powers, appointive powers, and the extent to which a governor's team is separately elected are each measured by

\footnotetext{
${ }^{2}$ Principal factors analysis with Varimax rotation. One factor unique factor was identified. Loadings were 0.338 for budgetary powers, 0.459 for appointive powers, and 0.508 for separately elected teams, where scores on each of
} 
Beyle on a 1 to 5 scale. The factor scores vary widely, with the governors of Georgia, South Carolina and Okalahoma being the institutionally weakest, while the governors in West Virginia, Maryland and New York were rated the strongest. Our variable is scaled to range from 0 to 1 , where states scoring 1 have governors with the strongest institutional powers. We expect that a more powerful governor will be more effective in managing the state.

Legislative Professionalism. We expect that the capacity of a state legislature to monitor and to improve public programs is directly related to the degree of "professionalism." Poorly managed states are more likely to have unprofessional legislatures as well. Labeled "citizen legislatures" by some scholars, part time, poorly paid and under-staffed legislatures are unable to become reservoirs of policy expertise (Franklin 2002, Kurtz 1992). Support staffs make committees more effective in processing legislation; fiscal analysis staffs improve the ability of legislatures to forecast revenues; leadership and caucus staffs enhance the strategic ability of party leaders; and member staffs enable the individual legislator to provide superior constituent services. Moreover, good pay attracts more talented people and enhances the stability of the legislature (Fiorina 1994).

Legislative professionalism varies widely. New Hampshire, with a population of just over a million, has a State House with 400 members and a 24 member State Senate. Meanwhile, 80 State Assembly members and 40 State Senators manage to represent California's thirty million citizens. State legislators in North Dakota earned just \$2,160 in all of 1998, and while low, it was more than ten times the $\$ 200$ annual salary for New Hampshire state legislators. Political scientists have euphemistically called these "citizen legislatures," as if the more professionally-run legislatures are not comprised of everyday citizens. Unprofessional 
legislatures tend to meet only a few months out of the year, leaving the day-to-day running of government up to the executive branch.

A typical way to measure a state legislature's professionalism includes assessing salaries, days in session per year, and state expenditures on the legislative infrastructure (King 2000, Mooney 1994, Kurtz 1991). Our measure of legislative professionalism is adopted from the Kurtz index, (Kurtz 1991; Hamm \& Moncrief 1999), which we update through the 1990s using King (2000). The data cleave clearly into legislatures that are professional and those that are not. There is, in reality, no middle ground. It is a dichotomous choice or condition, with 30 states having professional legislatures and 20 states without. Professional legislatures are found in, for example, California, New York and Michigan, while unprofessional legislatures are in places such as New Hampshire, Wyoming and New Mexico.

\section{$\underline{\text { Political and Social Environment }}$}

Social Capital. Social capital is "broadly conceptualized as the shared resource produced by trust in others, which in turn enables individuals to participate in organized networks that maximize political influence on those in power" (Pierce, Lovrich \& Moon 2002: 381; also Uslaner 2002a, 2002b, 2004, Putnam 2000, Skocpol \& Fiorina 1999, Fukuyama 1995). A state’s stock of social capital is composed of those "features of social organization, such as trust, norms, and networks, that can improve the efficiency of society by facilitating coordinated efforts" (Putnam 1993). Putnam's original concept was to measure "social connectedness" among individuals, a factor that has been shown to dramatically affect trust, employment and even health. For example, states where social capital is high tend to have low rates of violent crime.

There would seem to be a logical connection between greater social capital and the ease of managing a government. This is in part because a citizenry that is happier, healthier, and less prone to violence should be more content. More important, a high level of trust, shared norms, and networks of relationships should assist effective governance directly (Putnam 2000). Both 
Knack (2002) and Uslaner (2004) raise concerns over how social capital is measured by Putnam, but both also expect there to be a positive relationship between "connectedness" and government performance. $^{3}$

We expect that states with low levels of social capital are more difficult to govern. When people feel disconnected from their neighbors, they are less likely to participate in solving public problems. They trust their neighbors less; they are less generous; they trust their state governments less; and they are stingier with their tax dollars. The relationship between social capital and a state's income taxes is all the more interesting in that social capital is not related to how politically liberal or conservative a state's citizens may be.

We use Putnam's measure of social capital, as described in Appendix B. Putnam's measure is derived from a factor analysis, and it includes fourteen indicators ranging from what percentage of a state's respondents say that "most people are honest" to how frequently people volunteer in community groups. With this approach, the three states with the highest stocks of social capital are North Dakota, South Dakota and Vermont, whereas Nevada, Mississippi and Georgia are the most deprived of social capital.

Density of Good Government Groups. Generally speaking, the public views interest groups and their state lobbying efforts with disdain. Perhaps this has been justifiable, for as recently as World War II states often found themselves dominated by a single interest or a few powerful interests (Gray and Lowery 1996; Baumgartner and Leech 1998). Even today, several states have one or a few prominent interest groups such as the Mormon Church in Utah, Microsoft in Washington, agriculture/agribusiness in Arkansas, organized labor in Michigan and coal companies in West Virginia (Thomas \& Hrebenar 1999). However, looking across states, these

\footnotetext{
${ }^{3}$ State histories of social capital were related to the ability of the states to adopt social service programs during the 1880s, 1930s and 1990s (Rice \& Arnett 2001). More broadly defined, a state's "civic culture" is, by mechanisms still unclear, strongly correlated with the successful delivery of public policies (Rice \& Sumberg 1997). The quality of a city's roads and local services is higher in communities rich in social capital (Rice 2001), and a recent study of
} 
groups are much less powerful than the interest groups of old, such as the railroad industry in late nineteenth and early twentieth century.

We focus here on the relatively recent phenomenon of the emergence of "good government" groups, such as Common Cause and the League of Women Voters. These two groups have established a presence as an active lobbying force across the United States. These groups are distinctive in that their (public) interest is to promote better government rather than the furthering of private interests, which is the usual goal of business and labor lobbies.

The intended direct causal effect of good government groups is to improve the functioning of their political processes and make them more responsive to the needs of their citizenry, i.e., to make governments more "honest" or more "efficient." Thus, if we could hold other factors constant, we would expect that states with stronger good government groups would perform better than states with weak good government groups.

However, other factors are unlikely to be constant. In particular, states are uneven in how well they are managed, which may influence the formation of good government groups. Poor government tends to be a spur to the growth of good government groups. In Rhode Island, for example, a series of scandals in the 1980s spurred rapid growth in the membership of Common Cause, just as Nixon campaign excesses proved to be a fundraising boon at the national level. It was also corruption in Rhode Island that helped spur congressman Thomas Jencks, "the father of civil service reform" in the 1860 s, to run for office and lead a national campaign against patronage. Reformers often arise in the places that most need reform.

Hence, in considering the relationship between good government groups and state performance, we should expect that causality may flow in either direction, implying that neither a positive nor a negative regression coefficient should be surprising. If the predominant causal flow is from poor state performance to large good government groups, and there is plenty of 
variability in state performance to make this a possibility, we should expect to observe a negative relationship between state performance and good government. However, if the size of good government groups is predominantly determined by factors other than state performance, or if good government groups are so effective that their direct contributions swamp any negative selection effect, we should expect to observe a positive relationship.

Our measure for the density of good government interest groups is a state's combined per capita memberships in Common Cause and the League of Women Voters. By this measure, the membership densities are highest in Connecticut, Massachusetts and Vermont, and they are lowest in Mississippi, Alabama, and Louisiana.

Neighboring States. States learn from each other, and policy innovations diffuse through regions. Some states, such as California and New York, have traditionally been early-adopters of new policies, and those policy innovations then radiated out from the pioneering states (Walker 1969). We investigate whether states that do well in one category (financial management, say), are likely to have neighboring states that perform well in that category, too. (This strikes us as more telling than using regional dummy variables.) A "friends and neighbors" effect may be less pronounced today, with the National Governors Association and the National Conference of State Legislatures very active, than it was when Walker was writing. Still, we expect that one category - human resource management - might be particularly sensitive to the personnel approaches in neighboring states. States compete with each other for talented managers; competition tends to set established capabilities within a labor market.

To measure the "friends and neighbors" hypothesis, the grades of all neighboring states were averaged. The scores were then converted to a continuous 0 to 1 scale, with 0 being the 
"worst" neighborhood and 1 being the "best." Any state that borders on another state is considered its neighbor. ${ }^{4}$

\section{$\underline{\text { Business Environment }}$}

Business activity in a state was once subject to the serendipity of rivers and harbors, the fertility of farmlands, and other environmental worries such as mountain passes and weather patterns. The Massachusetts factories, roaring with endless waterpower, flourished by spinning and finishing raw materials from the agrarian South. Today's state business environment depends less on geography and more on public policy. With tax breaks and infrastructure improvements, states compete for new manufacturing facilities. State investments in education and basic research make some areas especially fertile ground for growing new companies. The state of Michigan, for example, funds ongoing research partnerships between the automobile industry and the University of Michigan. High technology startups tend to sprout near major universities, but to make the soil truly nourishing, new businesses may need tax breaks or zoning waivers, and so on.

Entrepreneurial Energy. We expect that states in which new businesses are readily incubated will have more effectively managed governments. First, even if causality runs from government management to entrepreneurship, we would expect a positive relationship. In an era when virtually all states are trying to attract new enterprises, the more effective ones will be able to create favorable conditions. Second, common third factors may play a role. Thus, there may merely be a climate of entrepreneurship and efficiency within a state, which positively affects both government and business. Third, business entrepreneurs tend to be a force for effective government. For example, they frequently push to improve both education and infrastructure.

\footnotetext{
${ }^{4}$ Alaska and Hawaii create difficulties, since they have no neighbor states. For our base regression, the entire West Coast region (California, Oregon, and Washington) was used as a crude proxy for their neighbors. To get better
} 
Thus, we should expect a positive relationship whether the primary flow is from government to business, business to government, or from some common third factor affecting both sectors.

Our measure of a state's entrepreneurial climate uses a 2001 study by the Corporation for Enterprise Development. Each state received an overall grade based on seventy measurements, with separate evaluations for economic development, business vitality, and development capacity. "Entrepreneurial energy" is a component of the business vitality scores, and that is what we use here. ${ }^{5}$ With this measure, Colorado, Utah, Oregon, Virginia and a few other states were especially fertile places for new businesses to succeed in the late 1990s. Wisconsin, West Virginia, Ohio and Arkansas proved to be especially unlikely places to find entrepreneurial energy.

Tax Burden. States raise revenues through a variety of measures. All but five states have sales taxes, but their levels vary considerably. (Mississippi and Rhode Island are at the top with sales taxes of seven percent.) Rhode Island is one of eleven states with no personal income tax. The highest marginal personal state income tax rates are twelve percent in North Dakota, eleven percent in Montana, and ten percent in Hawaii. Four states (South Dakota, Nevada, Wyoming and Washington) have no general income tax, although Nevada levies a substantial tax on the gaming industry. The mix of revenue sources in a state -- trading corporate, sales and personal income taxes off against each other -- often reflects a state's political ideology. Corporate tax rates tend to be higher in more politically liberal states, for example. ${ }^{6}$ Our political ideology variable measures liberalism. With tax burden we are worried about the overall cost of government, so we put the blend of revenue sources aside.

insight into the friends and neighbors analysis, we also redid the complete regression leaving out Alaska and Hawaii. None of our conclusions change with those two states in or out of the "friends and neighbors" analysis. ${ }^{5}$ It weighs (1) the number of companies applying for new employment service account numbers, per 1,000 workers, (2) the percentage of change in such new applications from 1998 to 1999, (3), the percent growth in employment at firms less than five years old, from 1993-1998, (4) the percentage of total jobs in high technology industries, and (5) proceeds of initial public offerings, per 1,000 firms. 
To indicate tax burden, we compute total tax revenue as a percentage of gross state product in 1996. A majority of states have state tax loads ranging between five and six percent of the state GDP, although there are notable outliers. At the low end, New Hampshire, South Dakota, Wyoming and Texas were below four percent in 1996, whereas Wisconsin, West Virginia and Hawaii were well over seven percent.

States select from a menu of options for taxation. Those with low sales taxes tend to have higher income taxes, and vice versa. Regardless of the source, the total tax burdens in states vary dramatically. New Hampshire, reflecting its "Live Free or Die" motto, had a 1996 tax burden of 2.45 percent of the state's gross domestic product (GDP). That figure includes local taxes and property taxes. The tax burden in neighboring Vermont was 5.75 percent of the state's GDP, and some of that money goes to providing public kindergartens, which are not available in New Hampshire. We can imagine three different predictions linking a state's tax load with state management performance. The relationship would be negative if corrupt and wasteful governments need to feed themselves. The relationship would be positive if governments cannot be effective with inadequate resources. Or there could be no relationship whatever if effectiveness depends on what states do with the resources, not on how many resources they have.

\section{Analysis and Discussion}

Our expectations for the effects of the ten independent variables are summarized in Table 2. Our dependent variable is a state's grade for any of our five areas of performance or overall GPA. To compute our regressions and overall GPA, a grade of A equals 12 points, an A minus 11 points, down to an $\mathrm{F}$ equal to one point. Where the hypothesis is marked with a plus sign, we expect a positive impact on state management, and vice versa. We expect that a strong governor,

\footnotetext{
${ }^{6}$ A state's support for the Democrat presidential candidate '88-'00 is positively correlated with the state's highest marginal corporate tax rate in 1997 (correlation $=0.351, \mathrm{p}<.02$ ).
} 
a professional legislature, social capital, political competition, good performance by neighboring states, and a strong entrepreneurial climate should mark successful state governments. A full correlation matrix is shown in Appendix B.

(Table 2 About Here)

Where we have a directional hypothesis, we employ 0.10 as a threshold for statistical significance, essentially employing a 0.05 chance of rejecting a true null. Where we have no directional hypothesis, we employ 0.05 as the threshold.

Results from a "seemingly unrelated regression" (SUR) analysis appear in Table 3. The coefficients can be read the same way one reads coefficients from standard OLS estimations. We use the SUR technique because the error terms in the other columns were positively correlated, as we'd expect for measures that are essentially tapping into a common dimension (Greene 2000). Accordingly, the most telling results are likely to be those based on the "average" grade for each state, shown in the final column of Table 3.

(Table 3 about here)

We find that a state's government institutions, the political and social environment, and a state's business environment each has an impact on state government performance. States with a strong stock of social capital perform better than other states, and holding everything else in the models equal, social capital is the single best predictor of a how well a state government is managed. Having a strong governor has no statistically discernable impact on how well a state is managed, but states with professional full-time legislatures score better on the GPP measures of management performance. States in which there is considerable "entrepreneurial energy" among businesses tend to be states that are better managed, especially in the "money" areas such as financial and capital management. 
Successfully managed states like Minnesota, Virginia, Utah and Washington all have an important factor in common. They are endowed with dense networks of social capital - and especially "generalized trust" (Uslaner 2004). ${ }^{7}$

Among the variables captured in our models, social capital is the biggest contributor to state government management of public programs. On average for a state's overall GPA, and holding everything else in our models constant, having a state go from poor to rich in social capital gains nearly 2.19 points out of 12 on the Government Performance Project measure of public management. We do not know to what extent this is because states with high levels of social capital are easier to govern, or because citizens are more likely to be heard.

Legislative professionalism also boosts how well a state is managed; yet the variance in professionalism among states is striking. It is difficult to imagine how legislatures that rarely meet and are poorly staffed can function in any effective way. The differences in legislative capacities, argue Keith Hamm and Gary Moncrief (1999), will matter more as power devolves from the federal government to the states. There are "shifts in fiscal responsibility [accompanying] shifts in policy-making power. Even traditional areas of state responsibility, such as prisons and education, seem to require more and more state legislative involvement these days" (1999: 146). States with professional legislatures, holding all else in our models constant, have their GPP average grades boosted by 1.16 points on the 12 point scale.

The density of good government groups tends to be higher in states that are poorly managed. We thought it possible that states with a higher proportion of civic-minded citizens would have better-managed governments as a result of reform and watchdog activities. Our results, however, suggest that people are sufficiently more likely to join Common Cause and the League of Women Voters when their states are performing poorly to overwhelm any true

\footnotetext{
${ }^{7}$ Similarly, Norris' (2001) evaluation of social capital in 47 countries finds that countries high in social capital are more likely to be democratized, and have expansive political rights and civil liberties. Their citizens are more politically tolerant of opposing views, and are more likely to be involved in politics.
} 
performance effect when looking cross sectionally. We have noticed that Common Cause membership drives are more successful in states that have recently experienced public scandals. ${ }^{8}$

Like people, states reside in "neighborhoods" such as "upper New England" and the "Midwest." We expected states to benefit from high performing neighbors, whether because of competition or learning. We do not find this in the overall GPA. However, neighboring states with good capital management and good human resource policies do tend to exhibit a positive impact on each other. This could be due to competition creating a relatively common standard, or some unobserved factor within the region producing similar outcomes for affected states.

While Friends and Neighbors conjures images of beneficial spillovers between neighboring states, this need not always be the case, even when our regressions find positive coefficients. Indeed, the original report on the GPP published in the February 1999, issue of Governing Magazine described “Kentucky’s aggressive recruitment policies, which include sending scouts to Louisiana and Alabama to pick up potential new state employees" (Barrett and Greene, 1999). We have heard similar stories about states going to neighbors to lure away the best forest rangers and game wardens. Perhaps such competition induces states whose neighbors have good human resource policies to implement such policies themselves, for Economics suggests that, at least in product markets, competition produces common prices and qualities.

Our analysis finds no relationship between a state tax burdens and how well a state manages that money. Higher taxes are not associated with better-managed governments. Low taxes do not signal that a state is well run.

The entrepreneurial energy in a state is, controlling for other things in the model, strongly correlated with higher grades for the state's management of programs. Improving from a bad to a good entrepreneurial climate increases a state's overall management performance by 1.73 points on the 12 point scale. A state's entrepreneurial energy is particularly predictive of how

\footnotetext{
${ }^{8}$ Rhode Island is the salient case, very poor in performance but strong in density of good group membership. If we exclude Rhode Island from our analysis, the coefficients on Good Government Groups remain negative, but the standard errors grow considerably.
} 
well a state "manages for results" and also on how it manages its money. To what extent these relationships come from effective business practices infusing state government, from a climate of efficiency helping both government and business, or from a capable state being able to develop a favorite business climate is not clear.

If the states are laboratories for democracy, we can learn from their success and their failures. Thanks to the Maxwell School's Government Performance Project, we have a pretty good sense of which states are managing their programs well and which ones are failing. In managing a state's information technology infrastructure, one would be wise to emulate Washington (A) instead of Hawaii (F). One could learn more about successful financial management techniques from Virginia (A) than from New York (D+). And when trying to attract and retain state employees, one would be better off following the example of South Carolina (A-) rather than that of Rhode Island (F). ${ }^{9}$

Success is not a happy accident visited on a few states. Public management succeeds in a business environment that encourages and rewards risk-taking. It succeeds in states that have dense networks of friends and associations, where inter-personal trust is fostered and political organizing is more easily done. And professional legislatures - well staffed and with members who are paid well enough to become full-time experts in various policy domains - appear to be a hallmark of successful state governments.

\footnotetext{
9 Though we have mounted and tested a range of hypotheses, most of which have strong theoretical support in the literature, we are often unable to disentangle causality. At times, we anticipated relationships that could go in either direction. In other specifications of the model, available by request from the authors, we explored the relationships between GPP scores and a state's political ideology, wealth, degree of political competition, levels of education and measures of social homogeneity. For those specifications, we were either left with meager results or we did not have strong theoretical priors about their impact on management scores. In the model summarized in Table 3 , however, we are reassured that four variables have significant explanatory power for the overall grade point averages assessed by the GPP in 1998.
} 
Table 1

1998 and 2000 State Grades

\begin{tabular}{|c|c|c|c|c|c|c|}
\hline State & $\begin{array}{c}\text { Financial } \\
\text { Management }\end{array}$ & $\begin{array}{c}\text { Capital } \\
\text { Management }\end{array}$ & $\begin{array}{c}\text { Human } \\
\text { Resources }\end{array}$ & $\begin{array}{l}\text { Manage for } \\
\text { Results }\end{array}$ & $\begin{array}{c}\text { Information } \\
\text { Technology }\end{array}$ & $\begin{array}{c}\text { Grade Point } \\
\text { Ave. }\end{array}$ \\
\hline Alabama & $\mathrm{D}+, \mathrm{C}+$ & D-, D+ & C-, D+ & $\mathrm{F}, \mathrm{D}+$ & $\mathrm{D}, \mathrm{C}-$ & $\mathrm{D}, \mathrm{C}-$ \\
\hline Alaska & $\mathrm{C}, \mathrm{C}$ & $\mathrm{C}+, \mathrm{C}$ & $\mathrm{C}-, \mathrm{C}$ & $\mathrm{C}-, \mathrm{C}-$ & C-, B & $\mathrm{C}, \mathrm{C}$ \\
\hline Arizona & B-, C & $\mathrm{D}+, \mathrm{C}+$ & $\mathrm{C}+, \mathrm{C}$ & B-, $\mathrm{C}+$ & $\mathrm{D}+, \mathrm{B}-$ & $\mathrm{C}, \mathrm{C}+$ \\
\hline Arkansas & B-, B- & $\mathrm{C}, \mathrm{C}$ & $\mathrm{C}+, \mathrm{C}$ & $\mathrm{D}, \mathrm{C}-$ & $\mathrm{D}, \mathrm{C}-$ & $\mathrm{C}-, \mathrm{C}$ \\
\hline California & C-, B- & $\mathrm{C}-, \mathrm{C}+$ & $\mathrm{C}-, \mathrm{C}$ & $\mathrm{C}-, \mathrm{C}-$ & $\mathrm{C}+, \mathrm{B}-$ & $\mathrm{C}-, \mathrm{C}+$ \\
\hline Colorado & $\mathrm{C}, \mathrm{C}+$ & $\mathrm{C}, \mathrm{B}$ & $\mathrm{B}, \mathrm{B}-$ & $\mathrm{C}-, \mathrm{C}+$ & $\mathrm{C}, \mathrm{C}$ & $\mathrm{C}+, \mathrm{C}+$ \\
\hline Connecticut & $\mathrm{C}-, \mathrm{C}$ & $\mathrm{C}+, \mathrm{B}-$ & $\mathrm{C}-, \mathrm{C}$ & $\mathrm{D}+, \mathrm{C}-$ & $\mathrm{D}+, \mathrm{C}+$ & $\mathrm{C}-, \mathrm{C}+$ \\
\hline Delaware & A-, A- & $\mathrm{B}, \mathrm{B}+$ & $\mathrm{B}, \mathrm{B}$ & $\mathrm{B}, \mathrm{B}$ & $\mathrm{B}, \mathrm{B}$ & $\mathrm{B}, \mathrm{B}+$ \\
\hline Florida & $\mathrm{B}, \mathrm{B}$ & $\mathrm{C}, \mathrm{B}-$ & $\mathrm{C}+, \mathrm{B}-$ & $\mathrm{B}, \mathrm{B}+$ & $\mathrm{C}-, \mathrm{C}+$ & $\mathrm{C}+, \mathrm{B}-$ \\
\hline Georgia & $\mathrm{C}+, \mathrm{B}-$ & $\mathrm{C}, \mathrm{B}-$ & B-, B- & $\mathrm{C}+, \mathrm{B}-$ & $\mathrm{C}, \mathrm{C}+$ & $\mathrm{C}+, \mathrm{B}-$ \\
\hline Hawaii & $\mathrm{C}-, \mathrm{C}$ & B-, B & $\mathrm{C}-, \mathrm{C}$ & $\mathrm{C}-, \mathrm{C}$ & $\mathrm{F}, \mathrm{C}-$ & $\mathrm{C}-, \mathrm{C}$ \\
\hline Idaho & $\mathrm{B}-, \mathrm{C}+$ & B-, B- & $\mathrm{C}, \mathrm{B}$ & $\mathrm{C}-, \mathrm{C}-$ & $\mathrm{D}+, \mathrm{B}$ & $\mathrm{C}, \mathrm{B}-$ \\
\hline Illinois & $\mathrm{B}+, \mathrm{B}+$ & B-, B & $\mathrm{B}, \mathrm{B}$ & $\mathrm{C}, \mathrm{B}-$ & $\mathrm{D}+, \mathrm{C}+$ & B-, B \\
\hline Indiana & $\mathrm{B}, \mathrm{B}-$ & $\mathrm{C}, \mathrm{B}-$ & $\mathrm{C}+, \mathrm{B}$ & $\mathrm{C}, \mathrm{B}-$ & $\mathrm{C}, \mathrm{B}-$ & $\mathrm{C}+, \mathrm{B}-$ \\
\hline Iowa & A-, A- & B-, B+ & $\mathrm{B}+, \mathrm{B}+$ & $\mathrm{B}+, \mathrm{A}-$ & $\mathrm{C}+, \mathrm{B}$ & $\mathrm{B}, \mathrm{B}+$ \\
\hline Kansas & B-, B- & $\mathrm{B}, \mathrm{B}$ & $\mathrm{B}+, \mathrm{B}+$ & $\mathrm{C}, \mathrm{C}+$ & $\mathrm{C}+, \mathrm{A}-$ & B-, B \\
\hline Kentucky & $\mathrm{B}+, \mathrm{A}-$ & A-, B+ & $\mathrm{B}, \mathrm{B}+$ & $\mathrm{B}, \mathrm{B}+$ & $\mathrm{C}+, \mathrm{B}+$ & $\mathrm{B}, \mathrm{B}+$ \\
\hline Louisiana & B-, C & $\mathrm{B}, \mathrm{B}$ & $\mathrm{C}+, \mathrm{B}$ & $\mathrm{B}, \mathrm{B}+$ & C-, B- & B-, B- \\
\hline Maine & B-, B- & C-, B- & $\mathrm{C}+, \mathrm{B}-$ & $\mathrm{C}, \mathrm{C}+$ & $\mathrm{C}, \mathrm{B}-$ & $\mathrm{C}, \mathrm{B}-$ \\
\hline Maryland & A-, A- & A-, A & $\mathrm{B}, \mathrm{B}$ & B-, B & C, B & $\mathrm{B}, \mathrm{B}+$ \\
\hline Massachusetts & $\mathrm{B}, \mathrm{B}-$ & $\mathrm{B}+, \mathrm{C}+$ & $\mathrm{C}+, \mathrm{B}-$ & $\mathrm{C}, \mathrm{C}$ & $\mathrm{C}, \mathrm{C}$ & B-, C+ \\
\hline Michigan & A-, A- & $\mathrm{B}+, \mathrm{A}-$ & $\mathrm{B}+, \mathrm{B}+$ & $\mathrm{B}, \mathrm{B}+$ & $\mathrm{B}+, \mathrm{A}-$ & $\mathrm{B}+, \mathrm{A}-$ \\
\hline Minnesota & A-, A- & $\mathrm{A}-, \mathrm{B}+$ & $\mathrm{C}+, \mathrm{C}+$ & $\mathrm{B}, \mathrm{B}$ & $\mathrm{B}, \mathrm{B}$ & $\mathrm{B}, \mathrm{B}$ \\
\hline Mississippi & $\mathrm{B}, \mathrm{B}$ & $\mathrm{B}, \mathrm{C}$ & $\mathrm{C}+, \mathrm{B}-$ & $\mathrm{C}, \mathrm{D}+$ & $\mathrm{C}-, \mathrm{C}+$ & $\mathrm{C}+, \mathrm{C}+$ \\
\hline Missouri & $\mathrm{A}-, \mathrm{B}+$ & $\mathrm{A}, \mathrm{B}+$ & $\mathrm{B}, \mathrm{B}+$ & A-, A- & $\mathrm{B}+, \mathrm{A}-$ & A-, B+ \\
\hline Montana & $\mathrm{B}, \mathrm{B}$ & $\mathrm{B}+, \mathrm{C}+$ & B-, C+ & $\mathrm{C}, \mathrm{C}$ & B-, C & $\mathrm{B}-, \mathrm{C}+$ \\
\hline Nebraska & $\mathrm{B}+, \mathrm{A}-$ & A-, B & B-, C & B-, B- & $\mathrm{C}+, \mathrm{C}+$ & $\mathrm{B}, \mathrm{B}-$ \\
\hline Nevada & B, B- & $\mathrm{B}+, \mathrm{B}$ & $\mathrm{D}, \mathrm{D}+$ & $\mathrm{C}, \mathrm{C}$ & $\mathrm{C}, \mathrm{C}-$ & $\mathrm{C}+, \mathrm{C}$ \\
\hline New Hampshire & $\mathrm{B}-, \mathrm{C}+$ & $\mathrm{C}, \mathrm{C}+$ & $\mathrm{B}, \mathrm{C}+$ & $\mathrm{D}+, \mathrm{D}$ & $\mathrm{C}, \mathrm{C}$ & $\mathrm{C}+, \mathrm{C}$ \\
\hline New Jersey & B-, B- & $\mathrm{B}+, \mathrm{A}-$ & $\mathrm{C}-, \mathrm{C}-$ & B-, B- & B-, B & B-, B- \\
\hline New Mexico & $\mathrm{C}-, \mathrm{C}+$ & $\mathrm{D}, \mathrm{C}-$ & B-, B- & $\mathrm{D}+, \mathrm{C}$ & $\mathrm{C}, \mathrm{C}+$ & $\mathrm{C}-, \mathrm{C}+$ \\
\hline New York & $\mathrm{D}+, \mathrm{C}+$ & $\mathrm{C}-, \mathrm{C}+$ & $\mathrm{C}, \mathrm{C}+$ & $\mathrm{B}+, \mathrm{C}-$ & $\mathrm{C}, \mathrm{B}$ & $\mathrm{C}-, \mathrm{C}+$ \\
\hline North Carolina & $\mathrm{B}, \mathrm{B}$ & $\mathrm{B}+, \mathrm{B}$ & $\mathrm{B}+, \mathrm{B}+$ & B-, B & $\mathrm{C}, \mathrm{B}+$ & $\mathrm{B}, \mathrm{B}$ \\
\hline North Dakota & B, B- & $\mathrm{B}+, \mathrm{B}$ & B-, B & $\mathrm{D}, \mathrm{C}-$ & B-, B- & B-, B- \\
\hline Ohio & $\mathrm{B}+, \mathrm{B}+$ & $\mathrm{B}, \mathrm{B}$ & $\mathrm{B}, \mathrm{B}$ & $\mathrm{C}+, \mathrm{B}$ & B, B- & $\mathrm{B}, \mathrm{B}$ \\
\hline Oklahoma & B-, C+ & $\mathrm{C}, \mathrm{C}$ & $\mathrm{C}-, \mathrm{C}-$ & $\mathrm{D}+, \mathrm{D}+$ & C-, B- & $\mathrm{C}, \mathrm{C}$ \\
\hline Oregon & B, B- & B-, B- & $\mathrm{C}+, \mathrm{C}$ & $\mathrm{B}+, \mathrm{B}$ & $\mathrm{C}+, \mathrm{C}$ & B-, C+ \\
\hline Pennsylvania & A-, A- & $\mathrm{B}, \mathrm{B}$ & $\mathrm{B}, \mathrm{B}+$ & B-, B & $\mathrm{B}, \mathrm{B}+$ & $\mathrm{B}, \mathrm{B}+$ \\
\hline Rhode Island & B-, B- & $\mathrm{C}+, \mathrm{C}+$ & $\mathrm{F}, \mathrm{C}-$ & $\mathrm{C}, \mathrm{C}$ & $\mathrm{D}, \mathrm{D}$ & $\mathrm{C}-, \mathrm{C}$ \\
\hline South Carolina & $\mathrm{B}+, \mathrm{A}-$ & B-, C+ & A-, A & B-, B & $\mathrm{B}, \mathrm{B}$ & $\mathrm{B}, \mathrm{B}+$ \\
\hline South Dakota & $\mathrm{B}+, \mathrm{B}-$ & B, B- & $\mathrm{C}+, \mathrm{B}-$ & $\mathrm{D}, \mathrm{D}$ & $\mathrm{B}, \mathrm{B}$ & $\mathrm{B}-, \mathrm{C}+$ \\
\hline Tennessee & $\mathrm{B}, \mathrm{C}$ & B-, C & $\mathrm{C}+, \mathrm{B}-$ & C, B- & $\mathrm{B}+, \mathrm{B}+$ & B-, B- \\
\hline Texas & $\mathrm{B}, \mathrm{B}+$ & C, B & B, B & $\mathrm{B}+, \mathrm{A}-$ & B, B- & $\mathrm{B}, \mathrm{B}$ \\
\hline Utah & A, A & A, A- & $\mathrm{B}+, \mathrm{B}-$ & $\mathrm{B}+, \mathrm{B}+$ & $\mathrm{B}+, \mathrm{A}$ & A-, A- \\
\hline Vermont & $\mathrm{B}, \mathrm{B}$ & B, B- & B-, C & B-, B & $\mathrm{C}, \mathrm{C}+$ & B-, B- \\
\hline Virginia & $\mathrm{A}, \mathrm{B}+$ & $\mathrm{A}, \mathrm{B}+$ & $\mathrm{B}, \mathrm{B}+$ & A-, A- & A-, A- & $\mathrm{A}-, \mathrm{B}+$ \\
\hline Washington & $\mathrm{A}-, \mathrm{B}+$ & A, A- & $\mathrm{B}+, \mathrm{A}-$ & $\mathrm{B}+, \mathrm{A}-$ & A, A & A-, A- \\
\hline West Virginia & B, B- & $\mathrm{C}+, \mathrm{C}$ & $\mathrm{C}+, \mathrm{C}+$ & $\mathrm{C}, \mathrm{C}$ & $\mathrm{C}, \mathrm{C}-$ & $\mathrm{C}+, \mathrm{C}$ \\
\hline Wisconsin & $\mathrm{C}+, \mathrm{C}+$ & A-, B+ & $\mathrm{B}+, \mathrm{A}-$ & $\mathrm{C}, \mathrm{C}$ & $\mathrm{B}, \mathrm{B}-$ & B, B- \\
\hline Wyoming & $\mathrm{C}+, \mathrm{B}-$ & $\mathrm{C}+, \mathrm{D}$ & $\mathrm{B}-, \mathrm{C}+$ & $\mathrm{C}, \mathrm{C}+$ & $\mathrm{D}+, \mathrm{C}-$ & $\mathrm{C}, \mathrm{C}$ \\
\hline
\end{tabular}

Source: Government Performance Project, Maxwell School of Government, 1999, 2001 
Table 2

Predicted Correlation with GPP Management Grades

\section{Government Institutions}

Strong Governor

Professional Legislature

$+\quad$ Strong governors can act more decisively.

$+\quad$ Expertise and good staff make managing more effective.

\section{Political, Social Environment}

Social Capital

Good Government Groups

Friends and Neighbors

$+\quad$ Fewer problems for govt to solve, and more participation.

+ or - Presence of groups keeps govt less corrupt. OR

People join such groups when govt. is ineffective.

$+\quad$ States learn from nearby successes.

\section{Business Environment}

Entrepreneurial Energy

Tax Burden

$+\quad$ Climate of efficiency in state helps govt $\&$ business.

o No prediction, but common in the literature. 
Table 3

Seemingly Unrelated Regression (SUR) Models of Overall and Individual Grades

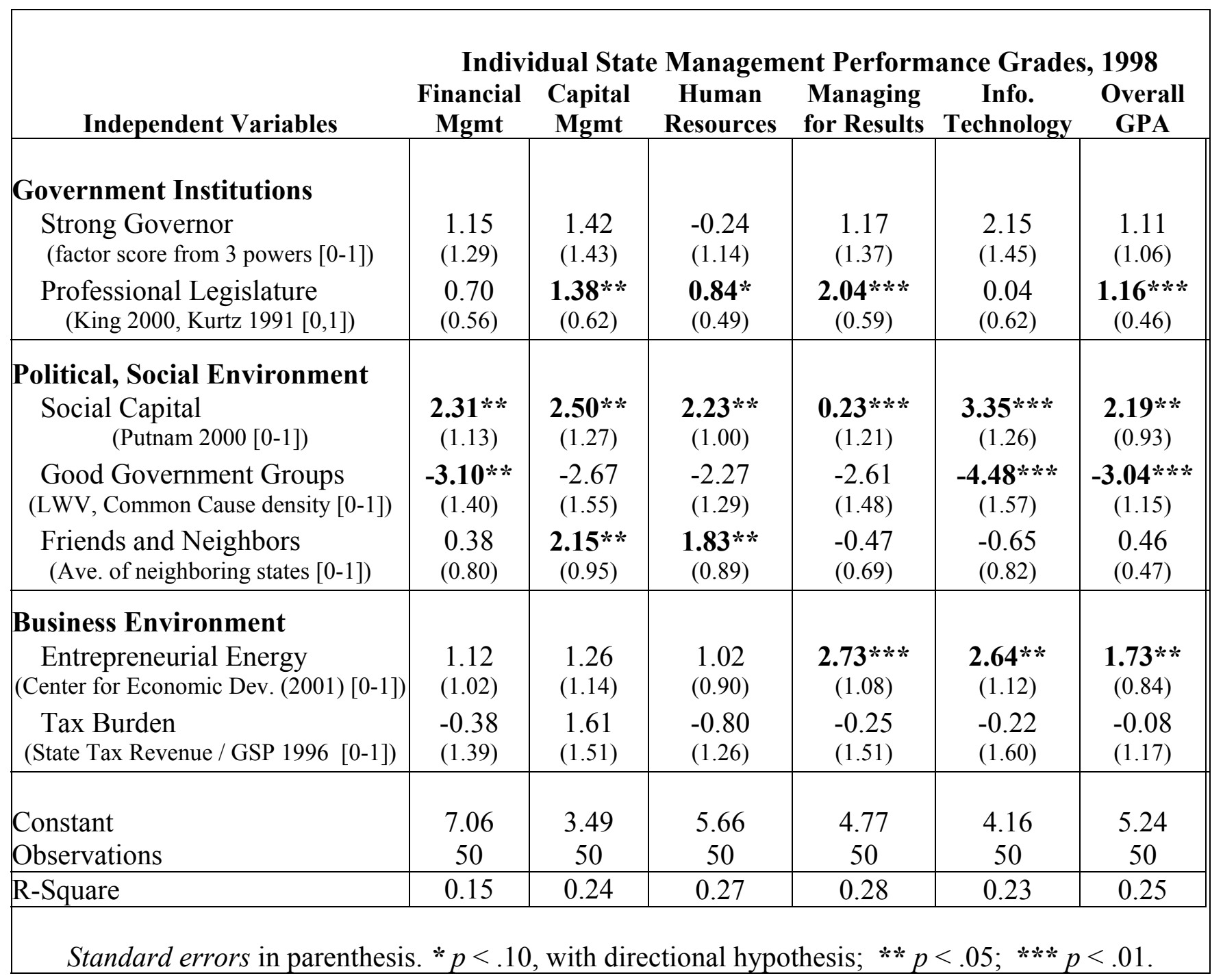




\section{APPENDiX A}

\section{GPP CRITERIA \& GRADES}

\section{Financial Management (FM)}

1. Have the state's forecasts of revenue and expenditure been accurate?

2. Over the course of recent years, has the state had a structural balance between ongoing revenues and expenditures?

3. Does the state have any counter cyclical planning devices such as rainy day funds? How much money is in them? How are they used?

4. Does the state adopt its budget on time?

5. What kind of investment and cash management policies does the state have? Do these tend to produce an appropriate balance between high return and avoidance of risk?

6. Does the state prudently manage its long-term debt?

7. Does the state have audited financial statements? Are they done in conformity with generally accepted accounting principles? Was the audit qualified? If so, were the qualifications material?

8. To what extent does the state use cost accounting to gauge the cost of delivering programs or services?

9. Is there an appropriate balance between expenditure control and flexibility for managers in pursuit of their objectives?

10. Apart from its annual report, does the state have timely, accurate and useful financial reporting?

11. Is there a multi-year perspective on budgeting and the future fiscal impact of state actions? Is it taken seriously?

12. How effectively does the state manage contract for goods and services?

13. Does the state have devices in place to ensure that budgets reflect policy priorities?

\section{Human Resource Management (HRM)}

1. Does the state have clear personnel policies and procedures? To what extent do those procedures limit its abilities to manage its workforce?

2. To what extent does the state do workforce planning and strategic analysis of future needs?

3. How quickly can agencies hire new employees? Do managers have appropriate authority to make hiring decisions?

4. How well does the state maintain and develop an appropriate mix of skills among employees, through training and other efforts?

5. Does the state motivate and reward employees through pay and other incentives? Can it reward superior performance?

6. Does the state have flexibility to discipline and terminate unproductive employees? 


\section{Information Technology Management (IT)}

1. Are enterprise-wide technology systems available to help managers? Do they provide the kind of data managers need?

2. Is there an effective mix of central coordination and agency control of information technology?

3. Does the state have a multi-year information technology planning process in place? How effectively is it used?

4. How quickly and easily can agencies procure the goods and services to meet their information technology needs?

5. What kind of effort goes into training IT staff and end users?

6. Does the state require cost-benefit analysis, return on investment or any other measure of value for its information technology projects? Does it follow through to see if promised benefits are delivered?

7. How well are information technology systems - notably Web sites - utilized to transmit information to citizens and other stakeholders? How well is the internet used to allow citizens to conduct transactions with the state?

\section{Capital Management (CM)}

1. How does the state establish its priorities for building? Is the process careful and depolarized? How well do state officials track the progress of capital projects?

2. Does state law have - and utilize - appropriate information to justify capital purchases?

3. How well does the state integrate planning for its capital budget with planning for its operating budget? Are the costs and savings from capital plans taken into account in making operating plans?

4. Does the state plan for routine and major maintenance, or at least have information about needs? Does it follow through? In the absence of plans, how good a job does the state do at maintaining its assets?

\section{Managing for Results (MFR)}

1. Does the state have a strategic plan? Do its agencies have plans? If so, are they effectively used?

2. Are citizens, unions, businesses and other stakeholders involved in the development of strategic plans?

3. To what extent has the state developed and used performance indicators and evaluative data by which progress toward results can be measured? Is it relying on measures of output, such as employee workload, or is it moving toward outcome measures that track results?

4. How effectively are performance measures used for policy making, management and evaluation of the government's progress toward its goals?

5. Are performance results communicated to citizens, elected officials and any other stakeholders? If so, how often? 


\section{APPENDIX B}

\section{DESCRIPTIVE STATISTICS AND CORRELATIONS}

Table B-1:

Descriptive Statistics

\begin{tabular}{|c|c|c|c|c|c|}
\hline Variable | & Obs & Mean & $\mathrm{D}$ & Min & $\operatorname{Max}$ \\
\hline-------------+----------1 & ------- & ------ & ----- & ------ & ---- \\
\hline Strong Governor & 50 & 0.524 & 0.235 & 0 & 1 \\
\hline Professional Legislature & 50 & 0.600 & 0.494 & 0 & 1 [dichotomous] \\
\hline Social Capital & 50 & 0.461 & 0.252 & 0 & 1 \\
\hline Good Government Groups & 50 & 0.385 & 0.257 & 0 & 1 \\
\hline Friends and Neighbors & 50 & 0.641 & 0.255 & 0 & 1 \\
\hline Entrepreneurial Climate & 50 & 0.550 & 0.315 & 0 & 1 \\
\hline Tax Burden & 50 & 0.540 & 0.190 & 0 & 1 \\
\hline
\end{tabular}

Table B-2:

Correlations among the 1998 GPP Grades, Independent Variables

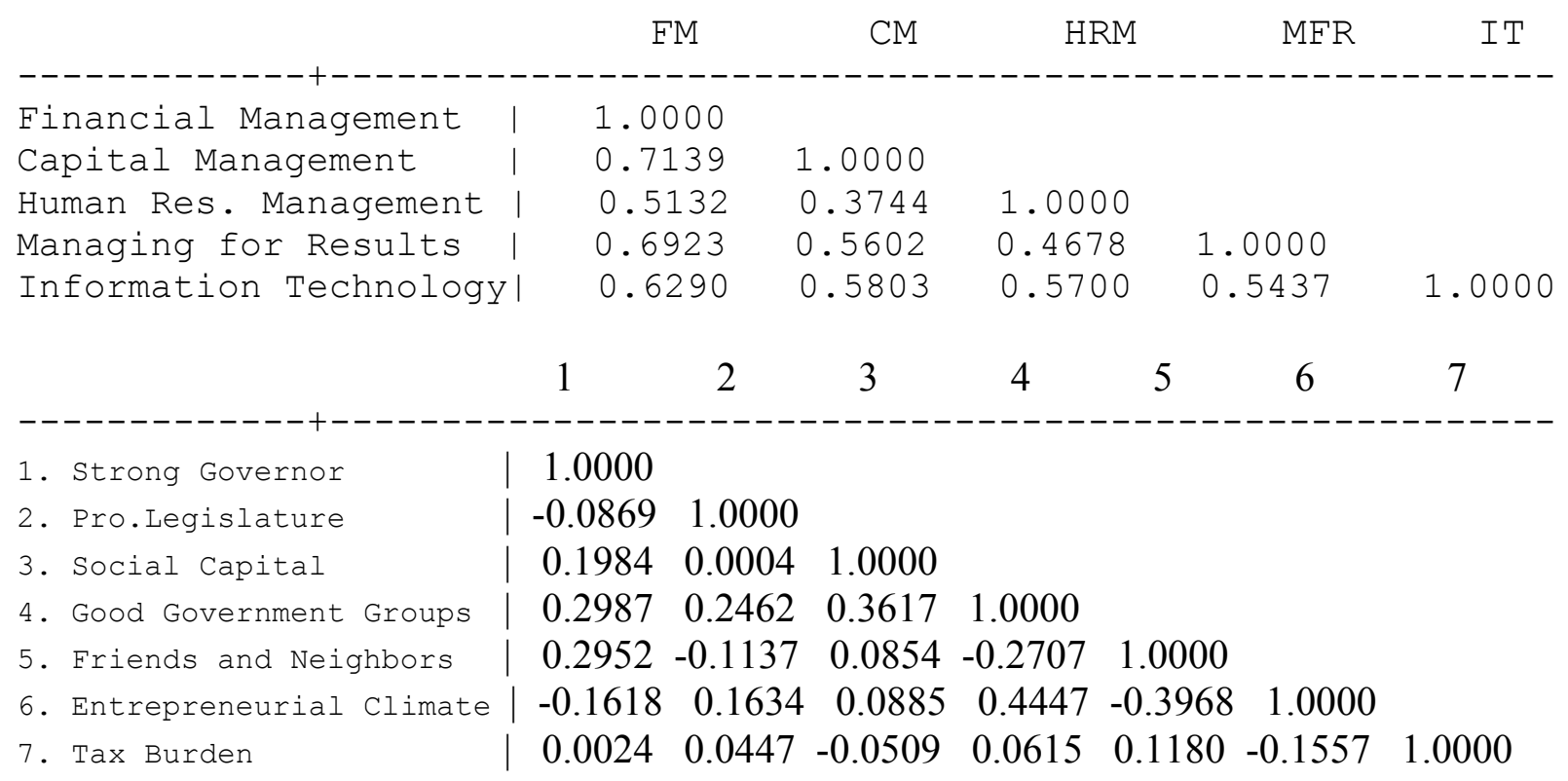


Table B-3:

State-Level Scores for Putnam's Social Capital Index

\begin{tabular}{|c|c|c|c|c|c|c|}
\hline Components of index of social capital & Source & Highest-ranking state & Highest score & $\begin{array}{c}\text { Lowest-ranking } \\
\text { state }\end{array}$ & Lowest score & Loading \\
\hline Served on committee for local organization last year & 1 & Minnesota & $17 \%$ & New Mexico & $4 \%$ & 0.88 \\
\hline "Most people can be trusted" vs. "Can't be too careful" & 2 & North Dakota & $67 \%$ & Mississippi & $17 \%$ & 0.88 \\
\hline Agree "Most people are honest." & 4 & Vermont & $74 \%$ & Mississippi & $54 \%$ & 0.84 \\
\hline Served as officer of local organization last year & 1 & Minnesota & $16 \%$ & New Mexico & $2 \%$ & 0.83 \\
\hline 501(c)(3) charitable organizations per 1000 pop & 5 & Vermont & $3.6 \%$ & Mississippi & $1.2 \%$ & 0.82 \\
\hline Civic and social organizations per 100,000 pop & 6 & Wyoming & $34 \%$ & Louisiana & $8 \%$ & 0.78 \\
\hline Attended public meeting on town or school affairs & 1 & New Hampshire & $33 \%$ & Georgia & $10 \%$ & 0.77 \\
\hline Organizational memberships per capita & 2 & North Dakota & $3.3 \%$ & North Carolina & $1.3 \%$ & 0.74 \\
\hline "I spend a lot of time visiting friends." & 4 & North Dakota & $48 \%$ & Nevada & $27 \%$ & 0.73 \\
\hline Entertained at home: frequency last year & 4 & Rhode I., Iowa, NH & $13 \%$ & Georgia & $9 \%$ & 0.67 \\
\hline Did volunteer work: frequency last year & 4 & Utah & $10 \%$ & Nevada & $5 \%$ & 0.66 \\
\hline Worked on community project: frequency last year & 4 & Vermont & $4.0 \%$ & Nevada & $1.7 \%$ & 0.65 \\
\hline
\end{tabular}

\begin{tabular}{|llc|}
\hline & Sources & Years covered \\
\hline 1 & ROPER REPORTS MONTHLY POLLS & $1974-1994$ \\
2 & GENERAL SOCIAL SURVEY & $1974-1996$ \\
3 & CENSUS BUREAU & 1988,1992 \\
4 & DDB NEEDHAM LIFE STYLE ANNUAL CONSUMER SURVEYS & $1975-1997$ \\
5 & NON-PROFIT ALMANAC & 1989 \\
6 & DEPT OF COMMERCE (FICA PAYMENT RECORDS) & $1977-1992$ \\
\hline
\end{tabular}

Professor Putnam did not include rankings for Alaska and Hawaii, so for them we temporarily constructed a new index based upon a subset of the measures in the Putnam index for which data were available for all 50 states. We incorporated our separate measures for Alaska and Hawaii into Putnam's scores, so for 48 of the 50 states we use Putnam's measure, and we use a highly correlated alternative for the remaining two.

Source: Personal Correspondence with Professor Robert Putnam 


\section{REFERENCES}

Altshuler, Alan A \& Robert D. Behn, eds. 1997. Innovation in American Government. Washington, DC: Brookings.

Barrett, Katherine, and Richard Greene. 1999. "Grading the States." Governing (February): 1790.

Baumgartner, Frank R., and Beth L. Leech. 1998. Basic Interests: The Importance of Groups in Politics and in Political Science. Princeton, NJ: Princeton University Press.

Besley, Timothy, and Anne Case. 2001. "Political Institutions and Policy Choices: Empirical Evidence from the United States." Typescript. London School of Economics, November 2001.

Beyle, Thad L. 1992. "Term Limits in the State Executive Branch.” Gerald Benjamin \& Michael Malbin, eds., Limiting Legislative Terms. Washington, DC: CQ Press.

Beyle, Thad L. 1999. "The Governors." In Politics in the American States: A Comparative Analysis, $7^{\text {th }}$ ed., edited by Virginia Gray, Russell L. Hanson, and Herbert Jacob. Washington, DC: CQ Press.

Blalock, Ann B., and Burt S. Barnow. 2001. "Is the New Obsession with Performance Management Masking the Truth About Social Programs?." In Dall W. Forsythe, ed. Quicker, Better Cheaper?: Managing Performance in American Government. Albany, NY: Rockefeller Institute Press.

Brudney, Jeffrey L, F. Ted Herbert and Deil Wright. 1999. "Reinventing government in the American states: Measuring and Explaining Administrative Reform". Public Administration Review. 59:19-30.

Chi, Keon, Drew Leathersby, Cindy Jasper, and Robert Eger. 1997. Managing for Success: A Profile of State Government for the $21^{\text {st }}$ Century. Lexington, KY: Council of State Governments.

Dirickson, Mary Kay. 2001. "Coast Beats State ACT Scores.” The Boloxi Sun Herald. Biloxi, Mississippi. September 6, 2001.

Elling, Richard C. 1992. Public Management in the States: A Comparative Study of Administrative Performance and Politics. Westport, CN: Praeger.

Elling, Richard C. 1999. "Administering State Programs: Performance and Politics." In Politics in the American States: A Comparative Analysis, $7^{\text {th }}$ ed., edited by Virginia Gray, Russell L. Hanson, and Herbert Jacob. Washington, DC: CQ Press. 
Erikson, Robert S., Gerald C. Wright, John P. McIver. 1993. Statehouse Democracy: Public Opinion and Policy in the American States. New York: Cambridge University Press.

Fiorina, Morris P. 1994. "Divided Government in the American States: A Byproduct of Legislative Professionalism?" American Political Science Review 88: 304-316.

Fiorina, Morris P. 1996. Divided Government, $2^{\text {nd }}$ ed. Needham Heights, MA: Allyn \& Bacon.

Forsythe, Dall W., ed. 2001. Quicker, Better Cheaper?: Managing Performance in American Government. Albany, NY: Rockefeller Institute Press.

Franklin, Daniel P. 2002. "Legislative Professionalism and the Delivery of Public Goods: A Comparative View from the States." Annual Meeting of the Southwest Social Science Association, New Orleans, March 29, 2002.

Fukuyama, Francis. 1995. Trust: The Social Virtues and the Creation of Prosperity. New York: Free Press.

Government Performance Project. 2001. Syracuse University, Maxwell School of Government.

Gray, Virginia, Russell L. Hanson, and Herbert Jacob, eds. 1999. Politics in the American States: A Comparative Analysis, $7^{\text {th }}$ ed. Washington, DC: CQ Press.

Gray, Virginia. 1973. "Innovation in the States: A Diffusion Study." American Political Science Review. 67:1174-85.

Gray, Virginia, and David Lowery. 1996. The Population Ecology of Interest Representation: Lobbying Communities in the American States. Ann Arbor, MI: University of Michigan Press.

Greene, William H. 2000. Econometric Analysis. $4^{\text {th }}$ Edition. Upper Saddle River, NJ: Prentice Hall.

Hamm, Keith E., and Gary F. Moncrief. 1999. "Legislative Politics in the States." In Politics in the American States: A Comparative Analysis, $7^{\text {th }}$ ed., edited by Virginia Gray, Russell L. Hanson, and Herbert Jacob. Washington, DC: CQ Press.

Harty, Harry P. 2002. "Performance Measurement: Fashions and Fallacies." Public Performance \& Management Review. 25:352-7.

Hays, Steven P. 1996. "Patterns of Reinvention: The Nature of Evolution During Policy Diffusion." Policy Studies Journal. 24:551-66.

Herbert, F. Ted, Deil Wright, and Jeffrey Brudney. 1992. "Challenges to State Governments: Policy and Administrative Leadership in the 1990s." Public Productivity and Management Review. 16:1-21. 
Hill, Kim Quaile \& Jan E. Leighley. 1996. "Political Parties and Class Mobilization in Contemporary United States Elections." American Journal of Political Science. 40:787804.

Hou, Yilin, Don Moynihan, and Patricia Ingraham. 2001. “Capacity, Management, and Performance: Exploring the Links.” Syracuse University: The Maxwell School of Public Management

Ingraham, Patricia W., Philip G. Joyce and Amy Kneedler Donahue. 2003. Managing for Performance. Baltimore, MD: Johns Hopkins University Press.

Ingraham, Patricia W., and Donald P. Moynihan. 2001. "Beyond Measurement: Managing for Results in State Government." In Dall W. Forsythe, ed. Quicker, Better Cheaper?: Managing Performance in American Government. Albany, NY: Rockefeller Institute Press.

Ingraham, Patricia W., and Amy E. Kneedler. 2000. "Dissecting the Black Box: Toward a Model and Measures of Government Management Performance.” In Jeffrey L. Brudney; Laurence O'Toole, Jr.; and Hal G. Rainey, eds. Advancing Public Management: New Developments in Theory, Methods, and Practice. Washington, DC: Georgetown University Press.

King, James D. 2000. "Changes in Professionalism in U.S. State Legislatures." Legislative Studies Quarterly 25(2): 327-343.

Knack, Stephen. 2002. "Social Capital and the Quality of Government: Evidence from the United States." American Journal of Political Science. 46:772-85.

Kurtz, Karl. 1991. "Understanding the Diversity of State Legislatures: The Red, White, and Blue Legislatures." Denver, CO: National Conference of State Legislatures.

Kurtz, Karl. 1992. "Understanding State Legislatures: Research and Commentary." Boulder, CO: Center for the Study of American Politics.

Light, Paul C. 1998. Sustaining Innovation: Creating Nonprofit and Government Organizations the Innovate Naturally. San Francisco: Jossey-Bass.

Meier, Kenneth J. \& Thomas M. Holbrook. 1992. "I seen my Opportunities and I Took 'Em:”" Political Corruption in the American States." Journal of Politics. 54:135-55.

Mintrom, Michael. 1997. "Policy Entrepreneurs and the Diffusion of Innovation." American Journal of Political Science. 41:738-770.

Mooney, Christopher Z. 1994. "Measuring U.S. State Legislative Professionalism: An Evaluation of Five Indices." State and Local Government Review. 26:70-8. 
Norris, Pippa. 2001. "Making Democracies Work: Social Capital and Civic Engagement in 47 Societies.” Typescript. Harvard University John F. Kennedy School of Government, October 17.

Pierce, John C., Nicholas P. Lovrich, Jr., and C. David Moon. 2002. "Social Capital and Government Performance: An Analysis of 20 American Cities.” Public Performance \& Management Review. 25:381-97.

Putnam, Robert D. 1993. Making Democracy Work: Civic Traditions In Modern Italy. Princeton, NJ: Princeton University Press.

Putnam, Robert D. 2000. Bowling Alone: Collapse and Revival of American Community. New York, NY: Simon \& Schuster.

Rice, Tom W. 2001. "Social Capital and Government Performance in Iowa Communities." Journal of Urban Affairs 23:375-89.

Rice, Tom W. \& Marshall Arnett. 2001. "Civic Culture and Socioeconomic Development in the United States: a View from the States, 1880s - 1990s.” The Social Science Journal. 38:39-51.

Rice, Tom W., and Alexander Sumberg. 1997. "Civic Culture and Government Performance in the American States.” Publius: The Journal of Federalism 27: 99-114.

Skocpol, Theda, and Morris P. Fiorina. Eds. 1999. Civic Engagement in American Democracy. Washington, DC: Brookings Institution Press.

Sparrow, Malcolm K. 2000. The Regulatory Craft: Controlling Risks, Solving Problems, and Managing Compliance. Washington, DC: Brookings Institution Press.

Thomas, Clive S., and Ronald J. Hrebenar. 1999. "Interest Groups in the States." In Politics in the American States: A Comparative Analysis, $7^{\text {th }}$ ed., edited by Virginia Gray, Russell L. Hanson, and Herbert Jacob. Washington, DC: CQ Press.

Uslaner, Eric M. 2002a. "Government Performance in Federal Systems." Federalism and Legislatures Conference, Innisfil, Ontario, April 4, 2002.

Uslaner, Eric M. 2002b. The Moral Foundations of Trust. New York: Cambridge University Press.

Uslaner, Eric. M. 2004. “The Civil State: Trust, Polarization, and the Quality of State Government." In Jeffrey Cohen, ed., Public Opinion in State Politics. Palo Alto, California: Stanford University Press. 
Walker, Jack L. 1969. “The Diffusion of Innovations Among the American States.” American Political Science Review. 63: 880-99.

Willoughby, Katherine G. and Julia E. Melkers. 2001. "Performance Budgeting in the States." In Dall W. Forsythe, ed. Quicker, Better Cheaper?: Managing Performance in American Government. Albany, NY: Rockefeller Institute Press. 